\title{
The role of specially protected natural areas in solving environmental problems of the Russian arctic (using the example of Vaygach Island)
}

\author{
Anna Aleinikova ${ }^{1,{ }^{*}}$, Maksim Byashkin ${ }^{2}$, Tatiana Gaivoron ${ }^{1}$, Galina Mainasheva ${ }^{2}$ and \\ Natalia Marsheva ${ }^{1}$ \\ ${ }^{1}$ Peoples' Friendship University of Russia (RUDN University), Faculty of Ecology, 6 Miklukho- \\ Maklaya St, Moscow, 117198, Russian Federation \\ ${ }^{2}$ Moscow City University, Institute of natural science and sport technology, Chechyulina St 1, \\ 105568, Moscow, Russia
}

\begin{abstract}
The Russian Arctic is a unified physical and geographical system of land and sea areas of Northern Eurasia, within which unique natural and historical and cultural objects are concentrated. The system of specially protected natural areas of the Russian Arctic preserves vulnerable arctic, tundra landscapes under conditions of various anthropogenic activities. In the face of modern climate change, monitoring of the transformation of the Arctic landscapes in specially protected natural areas is important. The landscape map compiled as a result of our own field and office studies shows 26 natural complexes. The most interesting for ecological tourism is the north-western part of the island. .By the example of Vaygach Island, the natural and historical-cultural possibilities of organizing a protected area, including the solution of environmental problems, are considered.
\end{abstract}

\section{Introduction}

Environmental problems in the Russian Arctic are caused by both natural and anthropogenic factors.

In the Arctic region, there are signs of global climate change: an increase in the temperature of surface air layers, a decrease in the area of land glaciers and sea ice, and permafrost.

Global climate change is leading to a widespread reduction in the permafrost area in the western Arctic. Cryogenic geomorphological processes - thermocarst, thermoabrasion, thermoerosion, solifluction - are activated [1]. Changes in abiotic components and factors in the development of geosystems cause changes in soils, vegetation, wildlife, and, as a result, natural complexes in general.

Main materials for our research were obtained during field studies in scientific expedition of the World Wildlife Fund (WWF) in 2013. The interpretation of satellite images and literary analysis were also used.

\footnotetext{
*Corresponding author: anshur@mail.ru
} 


\section{Results and discussion}

Warming changes plant communities in the Arctic, e.g. dwarf shrubs replace mosses, lichens, pollster plants, which reduces the resistance of tundra and Arctic soils to external influences. The natural habitats of Arctic animals are changing as they are forced to look for new sources of nutrition [2].

At the same time, under the conditions of a significant reduction in the anthropogenic impact on Vaygach Island (since the 90 s of the 20th century) due to climate warming, the restoration of affected natural complexes has begun. Boreal and hypoartic flora elements are spreading across the territory, high Arctic and Arctic species are being moved to the tops of the ridges.

Anthropogenic changes in the geosystems of the Arctic are caused not so much by traditional methods of nature management of the indigenous population as by modern intensive exploitation of natural resources. The development of mineral deposits on the Kola Peninsula, in the Timan-Pechora, Vorkuta, Pur-Nadym, Norilsk regions (production of oil, gas, coal, ferrous, non-ferrous, and precious metal ores) leads to the pollution of air, surface water, and soil. The area of natural geosystems is reduced due to the construction of cities and towns, laying of roads and pipelines.

In the 1990s, industrial activity in the Arctic was significantly curtailed, but there were destroyed and dilapidated buildings, up to 5 million tons of construction waste and 13 million rusty metal barrels, as well as rusty ships, cars, warehouses with tanks of fuel and lubricants. All this causes irreparable damage to Arctic geosystems. UNEP/GEF experts have identified more than 100 "hot spots" (impact areas) of accumulated environmental damage in the Russian Arctic, associated with industrial facilities where the environmental situation has reached a crisis or pre-crisis state [3]. The most relevant ones are, for example, Kovdor, the Pechora Bay, and the Taz Bay, which are located directly in the area of specially protected natural areas.

Conservation of Arctic landscapes is largely ensured by specially protected natural areas.

In the Russian Arctic at the beginning of 2012 there were 450 protected areas with a total area (excluding marine areas) of over 94.6 million hectares, which is about $16.2 \%$ of the total area of the Russian Arctic region. [4]. Among protected areas there are federal, regional, local protected areas, as well as reserves, national and natural parks, wildlife preserves and reserves (Fig. 1).

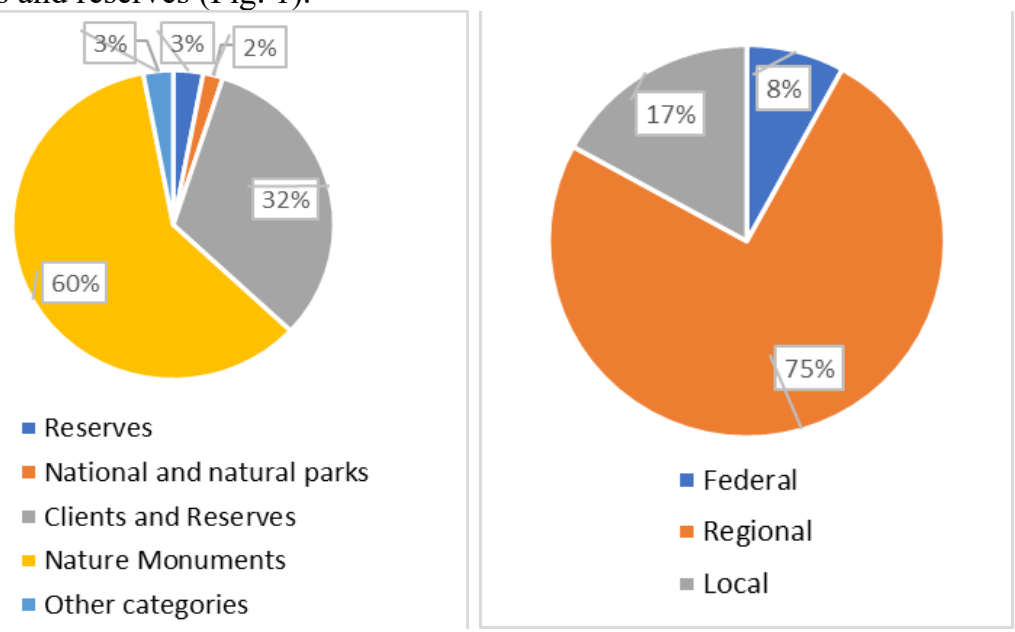

Fig. 1 The ratio of the number of specially protected natural areas of various categories of the Arctic region of Russia. 
The creation of new protected areas in the Arctic region will contribute to both preservation of Arctic landscape diversity and development of educational environmental tourism.

A variety of unique landscapes are located on the island of Vaygach, which were studied by a scientific expedition of the World Wildlife Fund (WWF) in 2013 to justify the establishment of a protected area. $[5]$.

Space images show clear north-western linearity of relief morphostructural elements

The main features of the landscapes of Vaygach Island are:

- spread of permafrost rock mass;

- diversity of the island relief - from 60-metre-high ridges separated by canyon-like river valleys to flat frost mound bogs (Fig. 2);
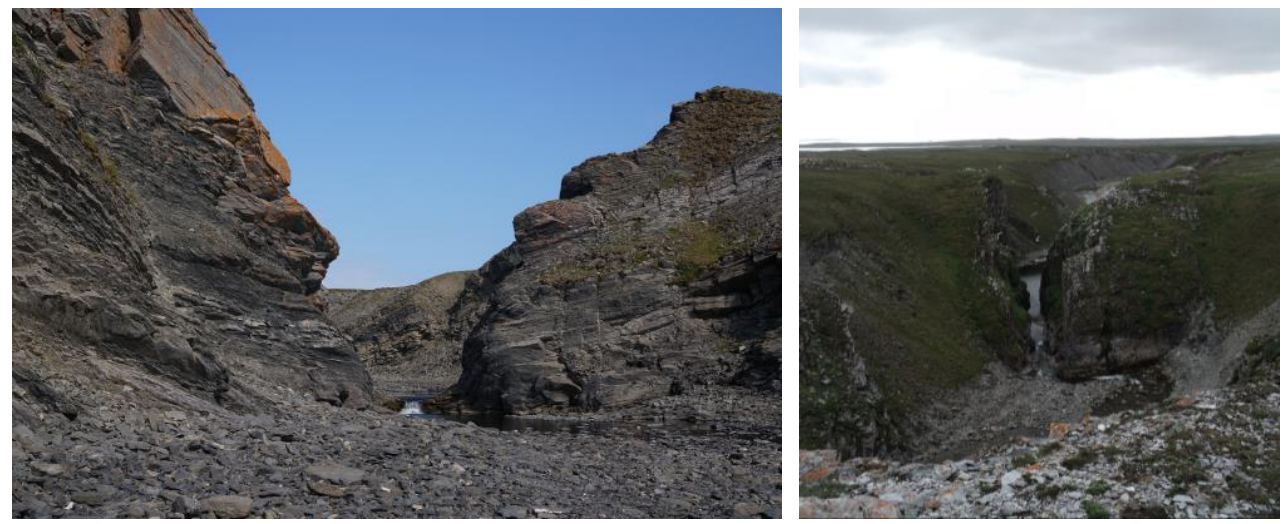

Fig. 2. a) Ranges and limestone massifs of Vaygach Island; b) Canyon-like valley with rich forb groups

- young and undeveloped river valleys;

- availability of periodically flooded saline coastal meadows - marshes or laidas;

- abrasion and abrasion-accumulative shores (Fig. 3); landscapes of floodplains of deep-cut valleys of small rivers and streams rich in biodiversity and endemics

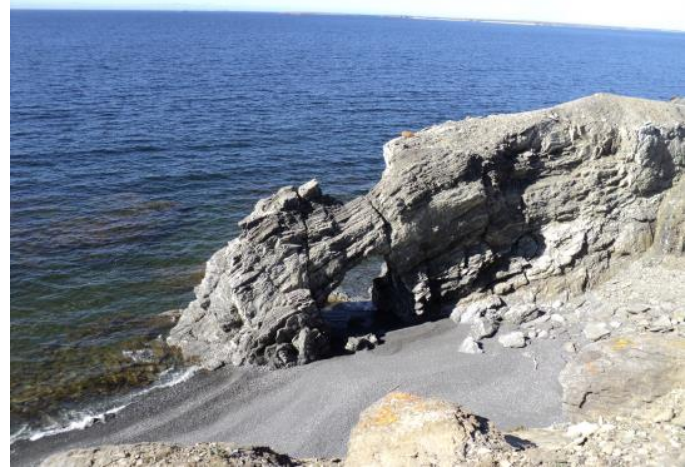

Fig. 3. Abrasive shores of Vaygach Island

A wide variety of arctic tundra landscapes are prevalent on the island, and the establishment of a protected area will ensure their conservation.

The landscape map compiled as a result of our own field and office studies shows 26 natural complexes (Fig. 4). The island is characterized by a variety of landscapes, the youth 
of river valleys, the presence of permafrost soils, flooded coastal meadows. The most interesting for ecological tourism is the northwestern part of the island.

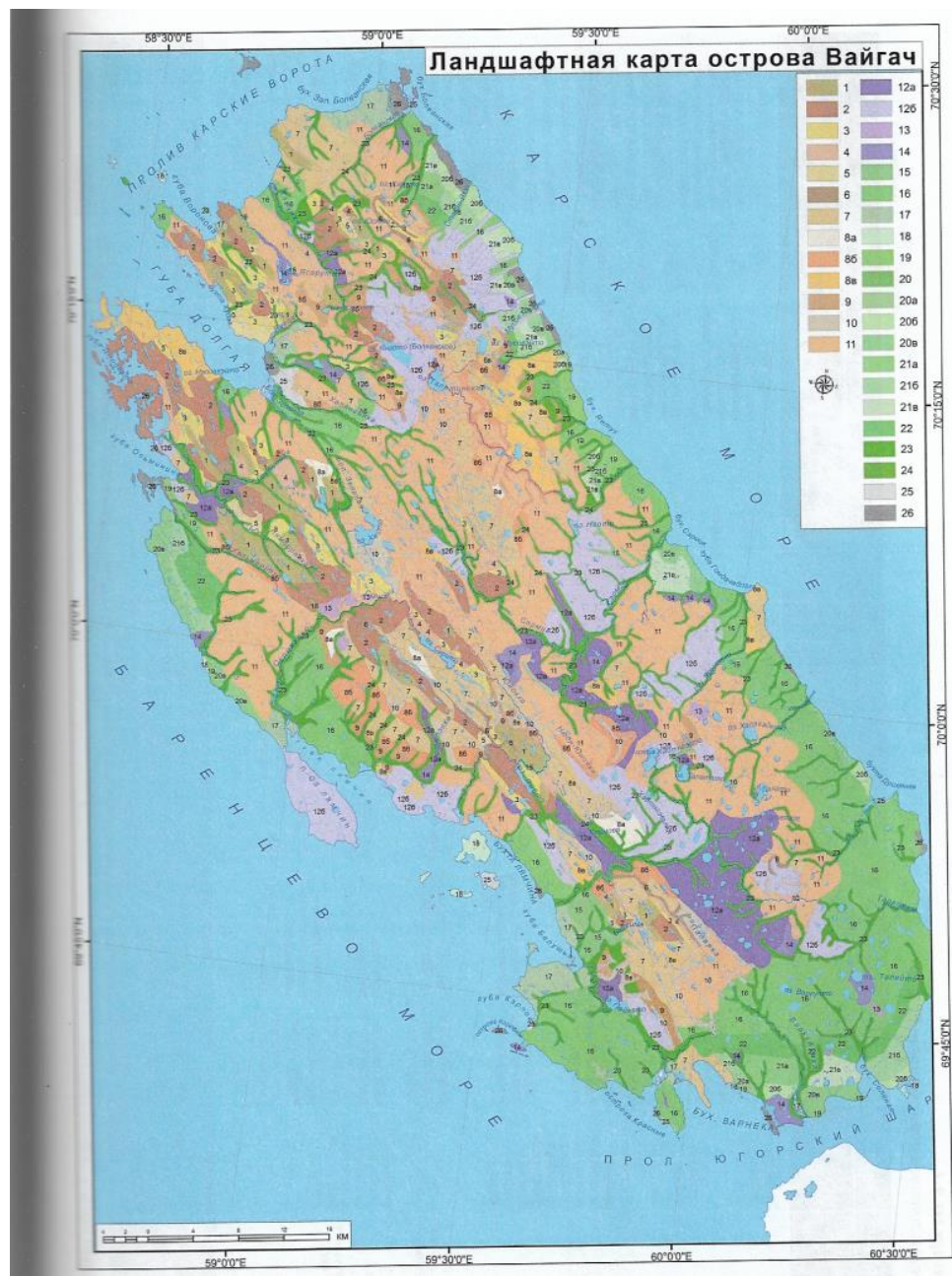

Fig.4. The landscape map of Vaygach Island

Historical and cultural sites on Vaygach Island have thus been preserved in slightly modified natural landscapes. The combination of the cultural component and the landscape of almost untouched polar tundra led to the formation of a unique phenomenon called the Arctic cultural landscape [6].

The Marine Arctic Complex Expedition (MACE) conducted field research on the Vaygach Island between 1986 and 2000 in order to search for and record historical and cultural sites [7].

Archaeological sites are:

- Litosalya settlement with flint tools of the Stone Age;

- Nenets sanctuaries with stone idols (houris), finds of wooden and iron objects, animal bone accumulations (Zayatsky Kamen, Great Bolvanskaya Mountain).

Historical monuments of Vaygach Island development were also discovered: 
- Pomor settlements of the 19th-20th centuries with finds of iron forged axes, wooden arrows for hunting fur-bearing animals, fragments of wooden oars, fragments of porcelain and glassware;

- Polar station (1912), camp of hydrographic expedition, trading station (20th century).

\section{Conclusion}

Modern climate change will lead to the transformation of landscapes of the island such as changes in the coastline, increased abrasion, swamping of coastal areas, lowland and flat landscapes of the island.

The landscape map compiled as a result of our own field and office studies shows 26 natural complexes. The island is characterized by a variety of landscapes, the youth of river valleys, the presence of permafrost soils, flooded coastal meadows. The most interesting for ecological tourism is the north-western part of the island.

In combination with natural resources of educational ecological tourism, i.e. unique polar landscapes, historical and cultural monuments provide an opportunity to study natural features in connection with the history of the development of Arctic regions. In many specially protected natural areas of Russia, protected objects also include historical and cultural sites (for example, protected areas of the Moscow region, Central Russia). Thus, the existing and newly organized protected natural areas of the Russian Arctic contribute to solving environmental problems, monitoring landscape changes following climate changes, as well as preserving not only Russia's natural, but also historical and cultural heritage.

\section{References}

1. M.M. Byashkin., T.D. Gavoron, Ecological Problems of Specially Protected Natural Areas of the Russian Arctic. Geography of Arctic Regions 2017, 66-69 (Stary Gorod, St. Petersburg, 2017) (in Russian)

2. G.M. Mainasheva, V.A. Tyurina, Trend of Changes in Some Natural Conditions in the Arctic. Geography of Arctic Regions 2017, 37-39 (Stary Gorod, St. Petersburg, 2017) (in Russian)

3. The Russian Arctic in the 21st century: environmental conditions and development risks: a reference manual publication (Feoria, Moscow, 2013) (in Russian)

4. M.S. Stishov, Specially Protected Natural Areas of the Russian Arctic: Current State and Development Prospects (WWF, Moscow, 2013) (in Russian)

5. A.A. Aleinikov, A.M. Aleinikova, M.V. Bocharnikov, P.M. Glazov, P.P. Golovlev, V.O. Golovleva, etc., Vaygach Island: Nature, Climate and People (WWF, Moscow, 2014) (in Russian)

6. M. Gavrilo, E. Ermolov, Protected by the State, 3, 16-34 (2015) (in Russian)

7. Vaygach Island. Cultural and Natural Heritage. Monuments of History of Arctic Exploration. Book 1. (Russian Research Institute of Cultural and Natural Heritage named after D.S. Likhachev, Polar Research Foundation, Moscow, 2000) (in Russian) 